\title{
EFFICIENCY OF REPAIRS PERFORMED WITHIN THE EMERGENCY REPAIR SUBSYSTEM OF MUNICIPAL BUS TRANSPORTATION SYSTEM
}

\author{
Mirosław Szubartowski \\ Wloclawek College of Enterprise and Technology \\ Łegska Street 20, 87-800 Wtoctawek, Poland \\ tel.: +48523620121 \\ e-mail:biuro@karor.com.pl
}

\begin{abstract}
In this paper there have been presented results of an analysis of repair efficiency for an emergency repair subsystem (technical service units) in a selected transportation system. The research object was a real system of municipal transportation, in a given urban agglomeration. Experimental data, necessary to determine values of indexes describing efficiency of repairs performed by the technical service units, come from a selected group of technical objects (city buses) used in the analyzed system. The data was obtained on the basis of experimental tests conducted within the studied system, employing a method of passive experiment, in conditions natural for the technical objects functioning. This work presents a method according to which the values have been determined and the analysis of efficiency of repairs performed within the emergency subsystem has been made. The values of repair efficiency assessment concern selected systems of the analyzed buses. The selection of these systems was made taking into consideration the number of the studied systems failures. The obtained results have been demonstrated in the form of tables and graphically, in charts. On this basis, there has been made an analysis of efficiency of repairs performed by emergency repair units. Due to its general character, the presented method can be used for an assessment of repair efficiency both within operation and maintenance systems of technical objects of different types and efficiency of repairs performed at particular repair stations, groups of stations or subsystems providing vehicles with serviceability.
\end{abstract}

Keywords: transport system, efficiency of repairs, technical service units

\section{Introduction}

The main purpose of the operation and maintenance systems of transport means is to meet the transport needs as a result of transport assigned tasks. The opportunity of the proper implementation of the transport tasks, depends critically on the reliability and availability of technical objects (transport means). A particular important issue in ensuring the required levels of reliability and availability of transport means is the reduction the number of failures and especially the elimination of defects arising due to defective implementation of the repair process. As a result of improperly performed repairs, repaired parts are re-damaged after a much shorter time periods that those set by the manufacturers life. Therefore, failure of technical objects should be divided into two sets $[5,7]$ :

- the primary damages, created after a time comparable to the stability given by the manufacturers as a result of the so-called normal wear of the elements,

- the secondary damages, arising after a much shorter time than the stability given by the manufacturers as a result of improperly performed repairs.

The main reasons of reducing the durability of the repair parts (the prevalence of secondary damage) are:

- use the incompatible with the assumptions repair technology,

- the use of unoriginal spare parts,

- the use of alternative tools and repair devices, 
- non-implementation schedules of servicing and repairing,

- insufficient qualified staff for repairs,

- inadequate implementation of disassembly and assembly processes,

- incorrect assessment of the diagnostic.

Increasing the durability of components as a result of the elimination of the causes of secondary damages is the fundamental problem that solution gives the possibility to influence the increasing levels of reliability and availability of transport means.

In the operation and maintenance systems of transport means, repair damaged of technical objects can be implemented both in the emergency repair subsystem (by the units of the technical emergency services) and in the maintenance subsystem (on stationary positions of the service station). One method of assessing the correctness implemented processes in the emergency repair subsystem or in the maintenance subsystem is to determine values of the efficiency of carried out repairs $[4,6,7]$.

In the article there have been presented results of an analysis of repair efficiency for an emergency repair subsystem in a selected operation and maintenance system of transport means system of municipal transportation. The values of repair efficiency assessment concern selected systems of the analyzed buses. The selection of these systems was made taking into consideration the number of the studied systems failures.

\section{Method of assessing the efficiency of repairs in the emergency repair subsystem}

In order to determine the efficiency of repair descriptors implemented in the emergency repair subsystem (by the units of technical emergency services), the criteria have been defined, under which the damages were divided into primary and secondary [5]:

- the basic criterion - limit kilometre mileage $D_{g r}^{(j)}$ determined from the average kilometre mileage between consecutive damages of the $j$-th bus system,

- the auxiliary criterion - the value of critical time $t_{k r}^{(j)}$, determined from the average time between consecutive damages of the $j$-th bus system.

In Tab. 1, it has been presented the classification of the damages on the primary and secondary, on the basis of accepted criteria (basic and auxiliary).

Tab. 1. Classification of damages based on the accepted criteria

\begin{tabular}{|c|c|c|c|c|c|}
\hline $\begin{array}{c}D_{i}^{(j)}>D_{g r}^{(j)} \\
t_{i}^{(j)}>t_{k r}^{(j)}\end{array}$ & $\begin{array}{c}D_{i}^{(j)} \leq D_{g r}^{(j)} \\
t_{i}^{(j)} \leq t_{k r}^{(j)}\end{array}$ & $\begin{array}{c}D_{i}^{(j)}>>D_{g r}^{(j)} \\
t_{i}^{(j)}<t_{k r}^{(j)}\end{array}$ & $\begin{array}{c}D_{i}^{(j)}<<D_{g r}^{(j)} \\
t_{i}^{(j)}>t_{k r}^{(j)}\end{array}$ & $\begin{array}{c}D_{i}^{(j)}<D_{g r}^{(j)} \\
t_{i}^{(j)}>>t_{k r}^{(j)}\end{array}$ & $\begin{array}{c}D_{i}^{(j)}>D_{g r}^{(j)} \\
t_{i}^{(j)}<<t_{k r}^{(j)}\end{array}$ \\
\hline $\begin{array}{c}\text { The primary } \\
\text { damage }\end{array}$ & $\begin{array}{c}\text { The secondary } \\
\text { damage }\end{array}$ & $\begin{array}{c}\text { The primary } \\
\text { damage }\end{array}$ & $\begin{array}{c}\text { The secondary } \\
\text { damage }\end{array}$ & $\begin{array}{c}\text { The primary } \\
\text { damage }\end{array}$ & $\begin{array}{c}\text { The secondary } \\
\text { damage }\end{array}$ \\
\hline
\end{tabular}

The basic criterion - limit kilometre mileage $D_{g r}^{(j)}$ :

$$
D_{g r}^{(j)}=\bar{D}^{(j)}-\widetilde{\sigma}^{(j)},
$$

where:

$\bar{D}^{(j)}$ - an average value of kilometre mileage between consecutive damages of the $j$-th bus system, $\tilde{\sigma}^{(j)}$ - value of standard deviation of the mileage $[\mathrm{km}]$ between the consecutive damages of the $j$-th bus system, determined from the corrected $f_{1-\alpha}^{(j)}$ t-Student distribution, depending on the number of measurements $n$ and significance level $\alpha$, according to the formula: 


$$
\begin{gathered}
\tilde{\sigma}^{(j)}=\sigma^{(j)} \cdot f_{1-\alpha}^{(j)}, \\
\sigma^{(j)}=\sqrt{\frac{\sum_{i=1}^{n}\left(D_{i}^{(j)}-\bar{D}^{(j)}\right)^{2}}{n-1},}
\end{gathered}
$$

where $D_{i}^{(j)}$ is value of the $i$-th realization kilometre mileage between the consecutive damages of the $j$-th bus system.

The auxiliary criterion - the value of critical time $t_{k r}^{(j)}$.

Based on analysis of operating research results concerning the times of suitability of buses used in tested urban transport system, it was assumed that the time intervals between defects of each bus systems are described by exponential decay. Then the criterion for describing the value of critical time was determined based on the dependence from (4) to (7). The critical time interval $t_{k r}^{(j)}$ concerns the initial range of value in which there are significant differences between the real distribution (population) and the empirical distribution (sample). Application of the critical region of exponential decay aims to bridge these differences. The discrepancies are caused by the occurrence, during operation of technical objects, secondary damages as a result of poor quality repairs of damaged bus systems $[1-3,5]$ :

$$
\begin{gathered}
F\left(t_{k r}^{(j)}\right)=1-e^{-\lambda^{(j)} \cdot t_{k r}^{(j)}}, \\
F\left(t_{k r}^{(j)}\right)=1-\alpha .
\end{gathered}
$$

Comparing equation (4) and (5) was obtained:

$$
\begin{gathered}
t_{k r}^{(j)}=-\frac{1}{\lambda^{(j)}} \ln \alpha, \\
\lambda^{(j)}=-\frac{1}{\bar{t}^{(j)}},
\end{gathered}
$$

where:

$\alpha-$ the level of significance,

$\bar{t}^{(j)}$ - average time between consecutive damages of the $j$-th bus system.

Repair efficiency index of the $j$-th bus system $E^{(j)}$ :

In order to determine values of repair efficiency index for each bus systems, carried out in the emergency repair subsystem (by units of technical emergency services) there were the following assumptions made:

- the number of repairs of the $j$-th bus system is equal to the number of damages of $j$-th system,

- the number of successful repairs of the $j$-th bus system is equal to the number of primary damages of $j$-th system,

- the number of unsuccessful repairs of the $j$-th bus system is equal to the number of secondary damages of $j$-th system.

Then values of repair efficiency index of the $j$-th bus systems are determined based on the dependence:

$$
E^{(j)}=\frac{n_{E}^{(j)}}{n_{E}^{(j)}+n_{I}^{(j)}}=\frac{n_{E}^{(j)}}{n^{(j)}}[\%],
$$

where:

$n_{E}^{(j)}-$ number of successful repairs of the $j$-th bus system, 
$n_{I}^{(j)}$ - number of unsuccessful repairs of the $j$-th bus system,

$n^{(j)}$ - total number of repairs of the $j$-th bus system,

or in case of assessing of repair efficiency of all bus systems, based on the dependence

$$
E^{(\Sigma)}=\frac{n_{E}^{(\Sigma)}}{n_{E}^{(\Sigma)}+n_{I}^{(\Sigma)}}=\frac{n_{E}^{(\Sigma)}}{n^{(\Sigma)}}[\%],
$$

where:

$n_{E}^{(\Sigma)}$ - number of successful repairs of the bus,

$n_{I}^{(\Sigma)}$ - number of unsuccessful repairs of the bus,

$n^{(\Sigma)}-$ total number of repairs of the bus.

\section{Results of research}

On the basis of the operating dates, obtained from studies in the real system of public bus transport, has been determined the number of repairs (damages) for each bus system, realized in the tested period of time. Operational data relate to repairs (damages) of 21 city buses, in the time period from 01.01.2007 to 31.12.2008, divided into three types of buses: Jelcz 181/1, Man NL and Volvo B10BE ( 7 buses in each group). The analyzed repairs were determined from the distribution of the repairs carried out in the emergency repair subsystem ERS (by the units of technical emergency services) and in the maintenance subsystem MS (on positions of service station). Tab. 2 presents the number of completed repairs with division into individual bus systems.

Tab. 2. Number o repairs of bus systems in the studied time period

\begin{tabular}{|l|c|c|c|c|}
\hline \multicolumn{2}{|c|}{ The system of bus } & \multicolumn{3}{c|}{ The number of repairs } \\
\hline \multicolumn{1}{|c|}{ Name } & Code & ERS & MS & ERS+MS \\
\hline The propulsion system & 1 & 675 & 974 & 1649 \\
\hline The chassis & 2 & 30 & 597 & 628 \\
\hline The electrical system & 3 & 815 & 703 & 1518 \\
\hline The guidance system & 4 & 298 & 501 & 799 \\
\hline $\begin{array}{l}\text { The compressed air supply } \\
\text { system }\end{array}$ & 5 & 384 & 368 & 752 \\
\hline The suspension system & 6 & 57 & 337 & 394 \\
\hline The body chassis & 7 & 248 & 454 & 702 \\
\hline Other & 8 & 4 & 44 & 48 \\
\hline
\end{tabular}

To analyze the efficiency of repairs, has been chosen the systems of buses with the largest number of repairs carried out in the emergency repair subsystem (by the units of technical emergency services):

- the propulsion system $\mathbf{- 1}$,

- the electrical system $\mathbf{- 3}$,

- the guidance system $-\mathbf{4}$,

- the compressed air supply system - $\mathbf{5}$,

- the body chassis - 7 .

Then, for systems of buses with the largest number of repairs carried out in the emergency repair subsystem, has been determined the values of the size necessary to evaluate the efficiency of repairs and criteria for classifying of damages for primary and secondary (Tab. 3):

- limit kilometre mileage $D_{g r}^{(j)}[\mathrm{km}]$,

- the critical region of the exponential distribution $t_{k r}^{(j)}[\mathrm{h}]$. 
Tab. 3. The values of parameters for assessing the efficiency of repair and the criteria for the distribution of damages selected primary and secondary bus systems

\begin{tabular}{|l|c|c|c|c|c|c|}
\hline Bus system code & $j$ & 1 & 3 & 4 & 5 & 7 \\
\hline $\begin{array}{l}\text { The average mileage between } \\
\text { damages [km] }\end{array}$ & $\bar{D}^{(j)}$ & 1872.37 & 2034.50 & 3864.98 & 4104.99 & 4400.03 \\
\hline $\begin{array}{l}\text { Standard deviation of mileage } \\
\text { between damages[km] }\end{array}$ & $\sigma^{(j)}$ & 368.92 & 312.82 & 568.43 & 397.04 & 431.85 \\
\hline $\begin{array}{l}\text { Standard deviation of mileage } \\
\text { between damages[km] including } \\
\text { t-Student index }\end{array}$ & $\widetilde{\sigma}^{(j)}$ & 723.08 & 613.13 & 1114.12 & 778.20 & 846.43 \\
\hline $\begin{array}{l}\text { The limit value of the mileage } \\
\text { between damages[km] }\end{array}$ & $D_{g r}^{(j)}$ & 1149.29 & 1421.37 & 2750.86 & 3326.79 & 3553.61 \\
\hline $\begin{array}{l}\text { The average time between } \\
\text { consecutive damages [h] }\end{array}$ & $\bar{t}^{(j)}$ & 219.15 & 240.86 & 458.66 & 486.60 & 521.62 \\
\hline $\begin{array}{l}\text { The critical region of exponential } \\
\text { distribution [h] }\end{array}$ & $t_{k r}^{(j)}$ & 656.51 & 721.54 & 1374.03 & 1457.73 & 1562.64 \\
\hline
\end{tabular}

On the basis of the values of the primary criterion and secondary criterion for the analyzed systems of urban buses operated in the studied transport system, were determined:

- the number of successful repairs carried out by units of technical emergency services,

- the number of unsuccessful repairs carried out by units of technical emergency services,

- index values of the efficiency of repairs carried out by units of technical emergency services (results are presented in Tab. 4-6 and in Fig. 1-3).

Tab. 4. Numbers of successful and unsuccessful repair and values of the repair efficiency index on the emergency repair subsystem, determined for selected systems of urban buses

\begin{tabular}{|c|c|c|c|c|}
\hline \multirow{2}{*}{$\begin{array}{c}\text { Code of bus } \\
\text { system }\end{array}$} & \multicolumn{4}{|c|}{ JELCZ 181/1 } \\
\hline
\end{tabular}




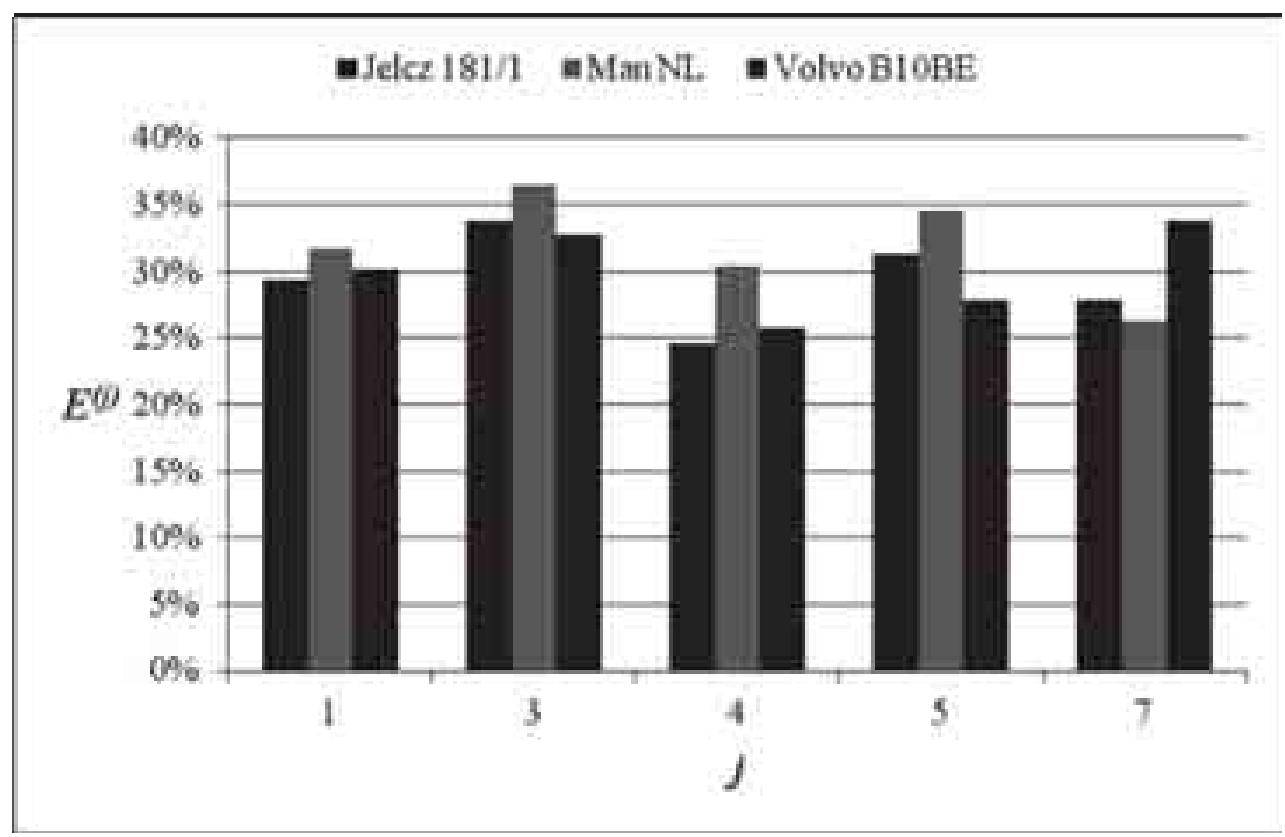

Fig. 1. The values of repair efficiency index performed in the emergency repair subsystem, determined for selected systems of urban buses

Tab. 5. Numbers of successful and unsuccessful repair and values of the repair efficiency index on the emergency repair subsystem, determined for selected systems of all tested buses

\begin{tabular}{|c|c|c|c|c|}
\hline \multirow{2}{*}{$\begin{array}{c}\text { Code of bus } \\
\text { system }\end{array}$} & \multicolumn{3}{|c|}{ Number of repairs } & \multirow{2}{*}{ Index $E^{(j)}$} \\
\cline { 2 - 5 } & $n_{E}^{(j)}$ & $n_{I}^{(j)}$ & $n^{(j)}$ & $30.5 \%$ \\
\hline 1 & 206 & 469 & 675 & $34.5 \%$ \\
\hline 3 & 282 & 533 & 815 & $26.6 \%$ \\
\hline 4 & 79 & 219 & 298 & $31.5 \%$ \\
\hline 5 & 121 & 263 & 384 & $29.5 \%$ \\
\hline 7 & 73 & 175 & 248 & \\
\hline
\end{tabular}

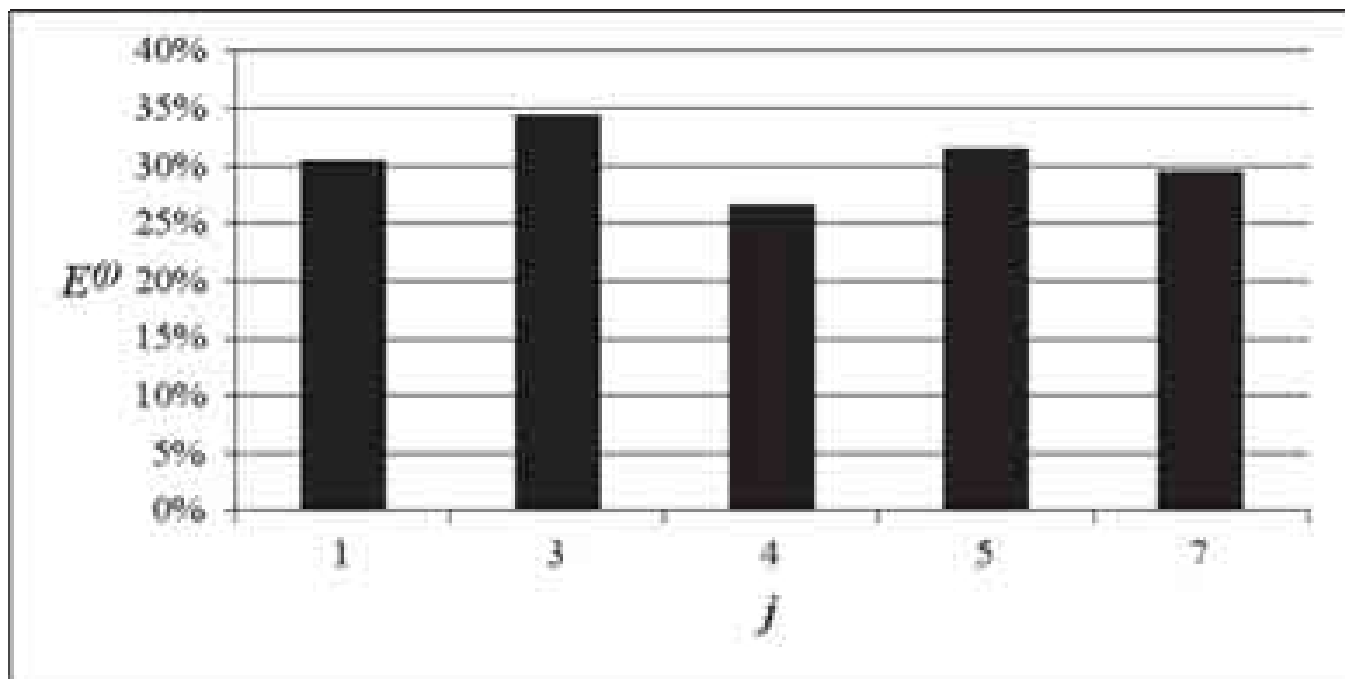

Fig. 2. The values of repair efficiency index performed in the emergency repair subsystem, determined for selected systems of all tested buses 
Tab. 6. Numbers of successful and unsuccessful repair and values of the repair efficiency index on the emergency repair subsystem, determined for individual types of tested buses

\begin{tabular}{|c|c|c|c|c|}
\hline \multirow{2}{*}{ Code of bus system } & \multicolumn{3}{|c|}{ Number of repairs } & \multirow{2}{*}{ Index $E^{(\Sigma)}$} \\
\cline { 2 - 4 } & $n_{E}^{(\Sigma)}$ & $n_{I}^{(\Sigma)}$ & $n^{(\Sigma)}$ & \\
\hline Jelcz 181/1 & 263 & 613 & 876 & $30.0 \%$ \\
\hline Man NL & 286 & 566 & 852 & $33.6 \%$ \\
\hline Volvo B10BE & 212 & 480 & 692 & $30.6 \%$ \\
\hline
\end{tabular}

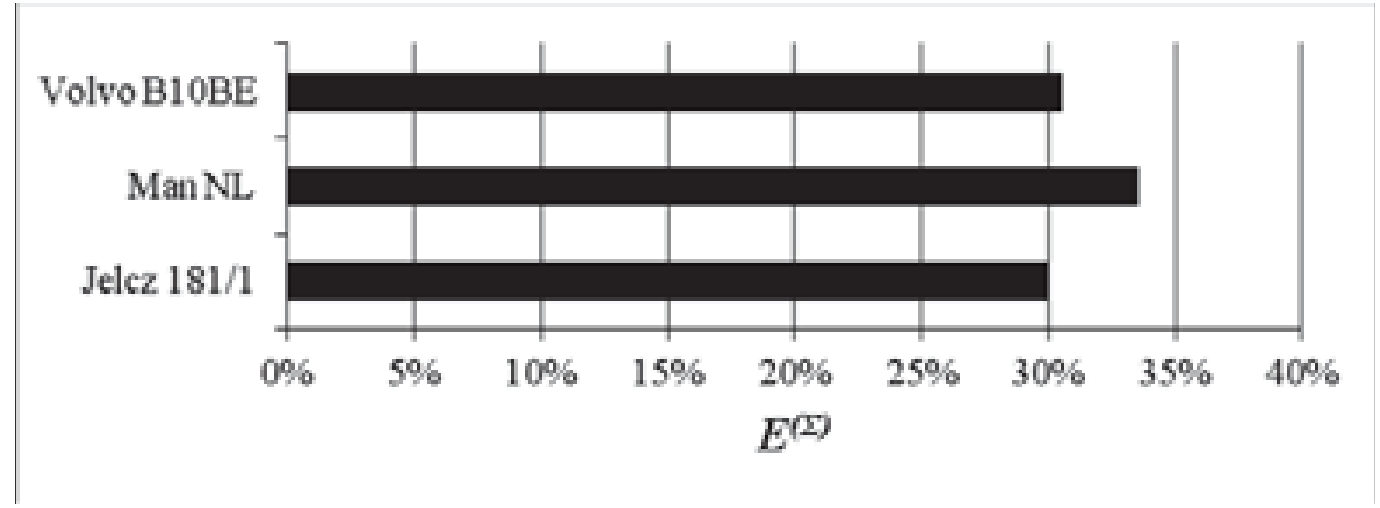

Fig. 3. The values of repair efficiency index performed in the emergency repair subsystem, determined for individual types of tested buses

\section{Conclusions}

Repairs carried out by the units of technical emergency services, due to their temporary nature, limited in time and lack of accurate diagnosis are often made unsuccessfully. As a result, the secondary damages of the same elements are formed at short intervals. This makes it necessary for re-intervention of the units of technical emergency services or implementation of repairs on positions of service station and thus the incurring additional costs.

The presented method of evaluation of repairs carried out in the means of transport operation systems (including the units of the technical emergency services) consists on determining and analyzing values of the repair efficiency index. Determined on the basis of research, values of the repair efficiency index carried out by the units of technical emergency services, for each subsystems of buses, are in the range from $24.6 \%$ to $36.5 \%$. The average values of the repair efficiency index for buses JELCZ 181/1 and VOLVO B10BE are similar and they are respectively $30.0 \%$ and $30.6 \%$. The greatest value of the repair efficiency index relates to buses MAN NL and is equal to 33.6\%. Differences between values of the repair efficiency index for the same systems in the different types of buses may result from various loads of the buses, the time of their operation and different design solutions of individual systems.

Based on the analysis of test results, it has been found that the bus system with the highest values of the repair efficiency index is for the electrical system. The smallest values of the repair efficiency index were characterized by the guidance system and the body chassis. The overall low values of the repair efficiency index carried out by the units of technical emergency services, may result to the fact that these individuals have limited equipment (tools and diagnostic devices) and repairs carried out on routes have often a temporary character and should be completed as soon as possible. These repairs are often performed only on that the technical object could finish the transport task or independently return to the depot. In order to improve the efficiency of repairs carried out by the units of technical emergency services, the units must be equipped with modern diagnostic and repair devices and specialized training of mechanics must be performed. 


\section{References}

[1] Bendat, S. J., Piersol, A. G., Metody analizy i pomiaru sygnałów losowych, PWN, Warszawa 1976.

[2] Bobrowski, D., Probabilistyka w zastosowaniach technicznych, WNT, Warszawa 1986.

[3] Firkowicz, S., Metody statystyczne w sterowaniu jakością, Wydawnictwo im. Ossolińskich, Wrocław 1977.

[4] Migawa, K., Szumiński, H., Wdzięczny, A., Metoda analizy skuteczności realizowanych napraw na przykładzie wybranego systemu eksploatacji środków transportu, II Konferencja Naukowo-Techniczna Problemy jakościowe, energetyczne i eksploatacyjne w maszynach cieplnych, pp. 115-122, Bydgoszcz-Duszniki Zdrój 2004.

[5] Woropay, M., Wdzięczny, A., Bojar, P., Szubartowski, M., Metoda oceny wpływu skuteczności realizowanych napraw na niezawodność $i$ bezpieczeństwo działania systemów transport miejskiego, Wydawnictwo Naukowe ITE, Radom 2008.

[6] Woropay, M., Wdzięczny, A., Muślewski, Ł., Migawa, K., The analysis and evaluation of the efficiency repair of the chosen subsystems of the means of transport, 11th Internantional Scientific Seminar on Developments in Machinery Design and Control, Vol. 9, Cerveny Klastor 2007.

[7] Woropay, M., Migawa, K., Szumiński, H., Wdzięczny, A., Analiza skuteczności realizowanych napraw podzespołów autobusów eksploatowanych w systemie komunikacji miejskiej, Międzynarodowa Konferencja Naukowa Transport XXI Wieku, pp. 415-424, Warszawa 2004. 